\title{
Recent occurrence of Fusarium wilt caused by Fusarium oxysporum on marjoram in Argentina
}

\author{
S. A. Gaetán ${ }^{\mathrm{A}} \mathrm{C}$, A. Curioni ${ }^{\mathrm{B}}$ and M. S. Madia ${ }^{\mathrm{A}}$

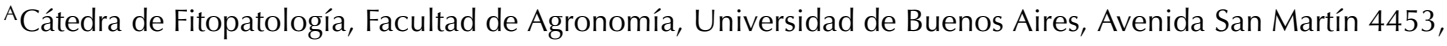 \\ CP 1417 DSE, Buenos Aires, Argentina. \\ B Departamento de Tecnología, Universidad Nacional de Luján, Luján, Provincia de Buenos Aires, \\ Argentina. \\ ${ }^{\mathrm{C} C o r r e s p o n d i n g ~ a u t h o r . ~ E m a i l: ~ s g a e t a n @ a g r o . u b a . a r ~}$
}

\begin{abstract}
In spring 2006, marjoram (Origanum vulgare) plants were found decayed and collapsed in Cordoba Province, in Argentina. Disease symptoms consisted of wilting, foliar necrosis, vascular discoloration, and death of infected plants. Several fungal isolates were obtained and identified as Fusarium oxysporum. Koch's postulates were completed. This appears to be the first record of a recent occurrence of Fusarium wilt of marjoram caused by this pathogen in Argentina.
\end{abstract}

Marjoram (Origanum vulgare), a perennial crop in the family Lamiaceae, is being increasingly grown commercially in Argentina to be processed as a dry herb. Commercial cultivations of marjoram are largely produced in open fields in Córdoba, Mendoza, San Juan and San Luis Provinces, although some smaller crops have been carried out in other areas in this country. During the last four years, marjoram has repeatedly shown decay and collapse symptoms in several production fields, especially in Luyaba (Transierra), in the midwest region of Córdoba Province.

In the spring of 2006, severe symptoms of a wilt were observed on marjoram cultivation developed under field conditions resulting in as much as $10-15 \%$ loss of plants. The wilt disease, affecting 1 to 2-year-old marjoram plants (Chilean and Argentinean marjoram cultivars), was observed in this region in one production field located at Luyaba. The infected plants appeared in irregular foci or patches throughout the rows. Symptoms observed were necrosis and drying of the leaves, usually on one sector of the plant, wilting and death (Fig. 1). At advanced stages of the disease, apical, brown, necrotic areas on the mature and youngest leaves occurred (Fig. 2). The necroses on infected leaves enlarged and coalesced to form large necrotic lesions that turned the entire leaf brown. Affected plants developed a general necrosis of the foliage resulting in wilting, premature defoliation and collapsing (Fig. 3). Internally, a vascular discoloration was evident in these plants throughout the basal stem parts while roots remained intact.

Fragments $(2-3 \mathrm{~mm}$ long) taken from vascular tissue of infected plants were plated on potato dextrose agar (PDA) after surface sterilisation with $2 \% \mathrm{NaOCl}$ for $2 \mathrm{~min}$. The plates were incubated in the dark for 2 days and then kept under $12 \mathrm{~h}$ alternations of near ultraviolet light and dark for 6 days. On the basis of morphological and cultural characteristics, four fungal colonies were consistently isolated, identified as Fusarium oxysporum (Booth 1971; Nelson et al. 1983) and used in the following studies. Pure colonies formed abundant microconidia on monophialides, falcate macroconidia, and terminal and intercalary chlamydospores.

Pathogenicity tests were performed on 2-month-old healthy marjoram plants. Koch's postulates were completed for two isolates by dipping the roots of seedlings in a conidial suspension $\left(2 \times 10^{5}\right.$ conidia $\left./ \mathrm{mL}\right)$ of a single-spore isolate for $30 \mathrm{~min}$. Plants were repotted in a sterilised soil mix (soil/sand; $2: 1$ ). The experiment was conducted in a greenhouse at 23 to $24^{\circ} \mathrm{C}$ and $75 \%$ relative humidity with no supplemental light. Within 16-18 days, all inoculated plants exhibited typical Fusarium wilt symptoms similar to those observed under field conditions, i.e.

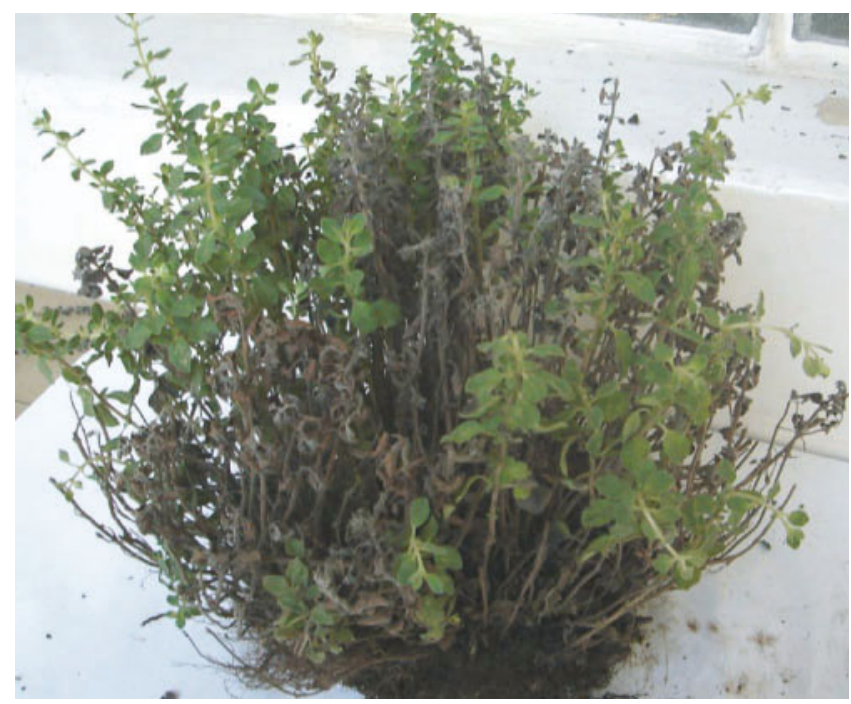

Fig. 1. Fusarium wilt caused by Fusarium oxysporum on a marjoram (O. vulgare) plant grown in Luyaba, Córdoba Province, in Argentina, showing necrosis and drying of the leaves on one sector of the plant. 


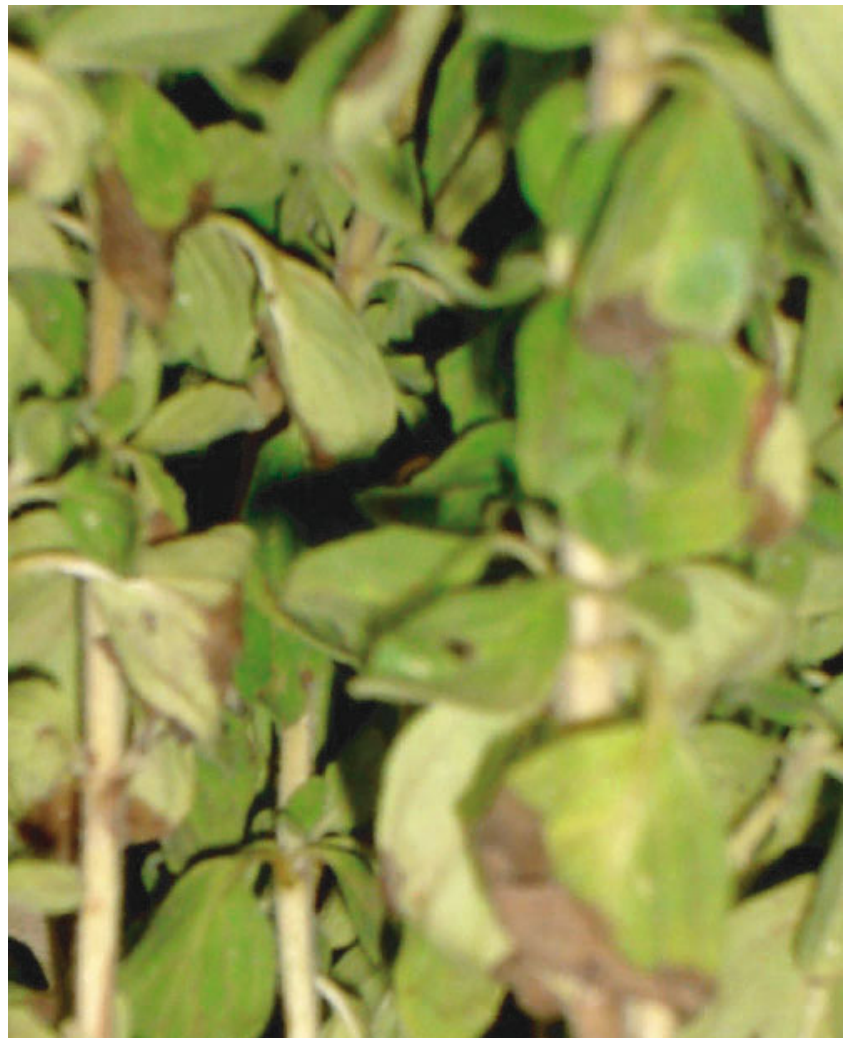

Fig. 2. Fusarium wilt caused by Fusarium oxysporum on a marjoram (O. vulgare) plant grown in Luyaba, Córdoba Province, in Argentina showing apical necrosis symptoms on foliage.

yellowing followed by necrosis and wilting of foliage, vascular discoloration, and the eventual collapse of the plant. Four weeks after inoculation, all of the treated plants were dead. No symptoms were observed on control plants, which were dipped only in distilled water. The fungus was successfully reisolated from the symptomatic plants, fulfilling Koch's postulates in all instances.

Fusarium oxysporum has previously been reported in 1994 causing a wilt disease in $O$. vulgare production fields located at Tunuyán and San Carlos, in Mendoza Province, in Argentina. The wilt disease was caused by $F$. solani and $F$. oxysporum (Garbagnoli and Gaetán 1994). Recently, an outbreak of a Fusarium crown and root rot on marjoram has been reported in Luyaba incited by F. solani (Gaetán et al. 2007). At this time, the new wilt disease could become a limiting factor in $O$. vulgare production and further information concerning these pathogens within the region is needed.

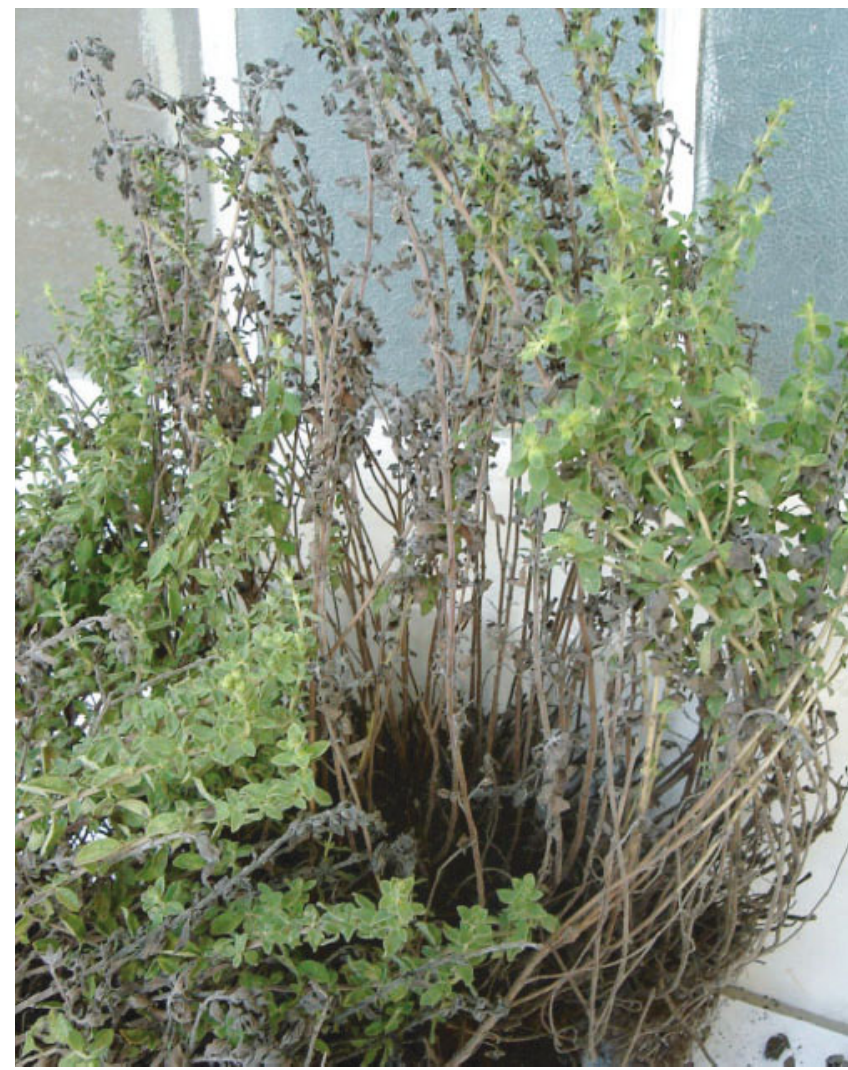

Fig. 3. Fusarium wilt caused by Fusarium oxysporum on a marjoram (O. vulgare) plant grown in Luyaba, Córdoba Province, in Argentina, exhibiting general necrosis, defoliation, and wilting on one part of the plant.

To the best of our knowledge, this is the first record on the recent occurrence of Fusarium wilt caused by $F$. oxysporum on commercial marjoram in open fields in Argentina.

\section{References}

Booth C (1971) 'The genus Fusarium.' (The Eastern Press: London) Gaetán SA, Madia MS, Perez A (2007) Recent outbreak of Fusarium crown and root rot caused by Fusarium solani on marjoram in Argentina. Australasian Plant Disease Notes 2, 15-16. doi: 10.1071/DN07006

Garbagnoli C, Gaetán SA (1994) Marchitamiento del orégano (O. vulgare L.) causado por especies del género Fusarium en la República Argentina. Fitopatología 29, 150-155.

Nelson PE, Toussoun TA, Marasas WFO (1983) 'Fusarium species: an illustrated manual for identification.' (Pennsylvania State University Press: University Park)

Manuscript received 21 May 2007, accepted 30 July 2007 